\title{
CHROMOSOMAL ABERRATIONS IN WORKERS OCCUPATIONALLY EXPOSED TO CHROMIUM, NICKEL AND COBALT
}

\author{
By \\ Ananian F.B.; Siha M.S. and Hussein N.M.H. \\ FROM \\ Industrial Medicine and Occupational Diseases Department, \\ Faculty of Medicine, Cairo University.
}

\begin{abstract}
Introduction: Combined exposure to chromium, nickel and cobalt occurs in many occupations as dental laboratory technicians, electroplating workers and welders. Dental laboratory technicians whom are the main concern in our study are exposed to chromium, nickel and cobalt metal alloys during casting, finishing and polishing of dental prosthesis (e.g. bridges, crowns, partial and complete dentures) and also to small amount of molybdenum, silica beryllium, boron and carbon.

The objective of this work was to evaluate the magnitude of exposure to these metals among dental laboratory technicians and their genotoxic effects.

Subjects and methods: The study included 30 dental technicians ( 24 male \& 6 females) and 20 comparable control subjects (15 male and 5 females) selected from outpatient clinic and nursing staff in Kasr ElAini hospital. Both groups were subjected to a prepared questionnaire including present, occupational, past and family history , measurement of serum chromium, nickel and cobalt levels, assessment of the chromosomal aberrations in the peripheral blood lymphocytes and measurements of the air levels of the chromium, nickel and cobalt at the work place.
\end{abstract}


Results and discussion: The levels of chromium, nickel and cobalt in serum were statistically significantly higher in exposed workers than in controls. There was a statistically significant increase of frequency of chromosomal breaks in exposed group than in controls after bleomycin stimulation and 11 of the exposed had chromosomal breaks $>35 \%$, while non of the controls exceeded this percentage. The use of personal protective equipments decreased the serum metal levels and this decrease was statistically significant in chromium and nickel. There was statistically significant positive correlation between serum chromium level and frequency of chromosomal breaks. The mean of the frequency of chromosomal breaks increased with age and longer duration of exposure but this increase was not statistically significant. No statistically significant correlation was found between smoking habit and the frequency of chromosomal breaks.

Four out of six exposed females (about 66\%) included in the study suffered from repeated abortions, still births and small sized fetuses and that they couldn't get pregnant except after a long vacation for at least 1 year. This indicates that $\mathrm{Cr}, \mathrm{Ni}$ and $\mathrm{Co}$ could have a genotoxic effect. Recommendations: We recommend the use of personal protective equipments by the dental technicians, periodic measurement of serum metal levels, periodic chromosomal studies by bleomycin induction of breakage culture, adequate history taking of any gestational problems and reconsidering the TLVs for the air levels of these metals.

\section{Introduction}

Combined exposure to chromium, nickel and cobalt occurs in many occupations as dental laboratory technicians, electroplating workers and welders (Park et al., 2004; Winder and Stacey, 2004). Exposure to these metals occurs via inhalation, ingestion or skin contact, from which the most common occupational route is inhalation. (Lide 1998; Wise et al., 2004). Dental laboratory technicians whom are the main concern in our study are exposed to chromium, nickel and cobalt metal alloys during casting, finishing and polishing of den- tal prosthesis (e.g. bridges, crowns, partial and complete dentures) and also to small amount of molybdenum, silica beryllium, boron and carbon. (Leghissa et al., 1994).

The most commonly used alloys are: a) Wiron Nickel Chrome alloys which contains approximately $75 \%$ nickel and $25 \%$ chromium, b) Cobalt chrome alloys which contains approximately $35-65 \%$ cobalt, $20-30 \%$ chromium and 0-30\% nickel. (Sherson et al., 1990).

Studies on the genotoxic effects of combined exposure of metals show much 
variability from the synergistic to the antagonistic effects. Elias et al., (1989) found increased blood and urinary level of chromium and nickel and increased gaps and breaks in chromosomes and chromatids in peripheral blood lymphocytes of welders. Ladon et al., (2004) detected increased blood level of chromium and cobalt and increased chromosomal translocations and aneuploidy in peripheral blood lymphocytes of people after using cobalt-chrome prosthesis metal-on-metal hip arthroplasty.

\section{Aim of the Work}

The aim of the present study is to evaluate the exposure and the genotoxic effects of the combined exposure to chromium, nickel and cobalt metals in dental laboratory technicians.

\section{Subjects and Methods}

The present study was conducted in 5 dental laboratories: a) Dental lab. of dental school, Cairo university. b) Dental lab. of dental school for boys, Alazhar university. c) Dental lab. of dental school for girls, Alazhar university. d) Alzahraa hospital dental lab. e) A private dental lab.

This study included two groups; an exposed and a control group. The exposed group consisted 30 healthy workers (24 males and 6 females) exposed to chromium, nickel and cobalt in the 5 dental labor- atories, their mean age was $39.9 \pm 11.58$ years ranging from 25 to 59 years. Duration of exposure was $16.3 \pm 9.77$ years ranging from 5 to 33 years. The control group included 20 comparable healthy subjects (15 males and 5 females) randomly selected from the industrial medicine and occupational diseases outpatient clinic and nursing staff in Kasr ElAini hospital who were not exposed to chromium, nickel or cobalt, or had received ionizing radiation for medical purposes recently, taking into consideration matching of age, sex, socioeconomic status and smoking habits. Their mean age was $39.1 \pm 11.63$ years, ranging from 26 to 59 years.

\section{Methods:}

Both groups were subjected to the following:

1- Subjects were informed about the nature of the study, and subsequently consented to it.

2- Detailed history taking according to a previously prepared questionnaire about:Personal, occupational history use of personal protective equipments, present, past and family history, history of drug intake or radiation exposure.

3- Biochemical estimations of serum chromium, nickel and cobalt: The serum chromium, nickel and cobalt level were 
measured by graphite furnace atomic absorption spectrophotometer with Zeeman background correction (Thermoelemental M6) (Christensen et al., 1999).

Putting into consideration that the normal level of these metals in the serum is less than $0.5 \mu \mathrm{g} / \mathrm{L}$ (Lauwyers and Hoet, 1993).

\section{4- Cytogenetic study:}

Lymphocyte cultures were set up using the technique of Moorhead et al., 1960. When we performed the conventional karyotyping study; no chromosomal aberrations were detected; we choose to perform induction of breakage culture which depend on increasing the fragility of the chromosomes by bleomycin, and hence the detection of susceptible persons to have chromosomal aberrations (Rooney and Czepulkowski, 1992).

The control level for this induction of breakage test is less than $35 \%$ aberrant cells per studied cells.

Metaphases were scored for structural and numerical aberrations. Some metaphases of each culture were photocopied from the computer unit of the electron mi- croscope. Results are reported as frequency of aberrant cells per studied cells.

5- Environmental air measurements:

It was done in the 5 laboratories to determine the air concentration of chromium, nickel and cobalt in the working place using a pump connected with a filter cassette (Millipore cellulose ester filters) putted in the breathing zone of workers during the whole working shift. Analysis was performed by the graphite furnace atomic absorption spectrophotometry (Benova et al., 2002).

The mean and SD of air metal levels in the visited laboratories were as follows:

Chromium air level $=0.213 \pm 0.0499 \mu \mathrm{g} /$ $\mathrm{L}$, Nickel air level $=1.255 \pm 0.1692 \mu \mathrm{g} / \mathrm{L}$, Cobalt air level $=0.028 \pm 0.0317 \mu \mathrm{g} / \mathrm{L}$.

These levels are within normal according to the TLVs for 8 hours working shift air levels updates putted by OSHA 2006.

6- Statistical analysis was done by using the following: Calculation of the mean value, Standard deviation, Chi square test, Student-t test, Correlation coefficient between variables ( $\mathrm{r}$ value) $\mathrm{P}$ value of student $t$ test or Chi square test (the value of significance is $<0.05$ ). 


\section{Results}

Table (1): Demographic characteristics of the studied groups:

\begin{tabular}{|c|c|c|c|c|c|c|}
\hline \multirow{2}{*}{} & \multirow{2}{*}{} & \multicolumn{2}{|c|}{$\begin{array}{c}\text { Exposed } \\
\mathrm{N}=30\end{array}$} & \multicolumn{2}{c|}{$\begin{array}{c}\text { Control } \\
\text { N=20 }\end{array}$} & \multirow{2}{*}{ P. value } \\
\cline { 3 - 6 } & & No. & $\%$ & No. & $\%$ & \\
\hline \multirow{2}{*}{ Sex } & Males & 24 & 80 & 15 & 75 & 0.68 \\
& Females & 6 & 20 & 5 & 25 & $(>0.05)$ \\
\hline \multirow{2}{*}{$\begin{array}{c}\text { Smoking } \\
\text { habit }\end{array}$} & Smokers & 11 & 36.7 & 6 & 30 & 0.63 \\
\cline { 2 - 6 } & Non smokers & 19 & 63.3 & 14 & 70 & $(>0.05)$ \\
\hline \multirow{2}{*}{$\begin{array}{c}\text { Age } \\
\text { Smoking index }\end{array}$} & & Mean & S.D. & Mean & S.D. & \\
\cline { 2 - 6 } & & 39.93 & 11.58 & 39.10 & 11.63 & $0.81(>0.05)$ \\
& & 393.64 & 281.76 & 365 & 265.89 & $0.73(>0.05)$ \\
\hline
\end{tabular}

No statistically significant difference between the exposed and controls in the demographic characteristics.

Table (2): Comparison of serum chromium, nickel and cobalt levels among the studied groups:

\begin{tabular}{|c|c|c|c|}
\hline (Mean \pm S.D.) & $\begin{array}{c}\text { Exposed } \\
\mathrm{N}=30\end{array}$ & $\begin{array}{c}\text { Control } \\
\mathrm{N}=20\end{array}$ & P. value \\
\hline Serum chromium & $6.5760 \pm 5.5017$ & $0.2620 \pm 0.09731$ & $<0.001^{*}$ \\
\hline Serum nickel & $9.4670 \pm 6.5885$ & $0.5165 \pm 0.3973$ & $<0.001^{*}$ \\
\hline Serum cobalt & $5.9647 \pm 5.0067$ & $0.9640 \pm 0.4589$ & $<0.001^{*}$ \\
\hline
\end{tabular}

The serum chromium, nickel and cobalt levels are higher among the exposed group and this difference is statistically significant.

*: statistically significant

Table (3): Serum chromium, nickel and cobalt levels according to the use of personal protective equipment in exposed group:

\begin{tabular}{|c|c|c|c|}
\hline (Mean \pm S.D. $)$ & $\begin{array}{c}\text { Users } \\
\mathrm{N}=18\end{array}$ & $\begin{array}{c}\text { Non users } \\
\mathrm{N}=12\end{array}$ & P. value \\
\hline Serum chromium & $3.2194 \pm 2.9955$ & $11.6108 \pm 4.4544$ & $<0.001^{*}$ \\
\hline Serum nickel & $6.8001 \pm 5.0495$ & $13.4658 \pm 6.7795$ & $<0.05^{*}$ \\
\hline Serum cobalt & $5.6867 \pm 4.5525$ & $6.3817 \pm 5.8085$ & $>0.05$ \\
\hline
\end{tabular}

There is a decrease in serum level of metals with use of PPE and this decrease is statistically significant with serum chromium and nickel levels.

*: statistically significant. 
Table (4): Correlation between serum levels of metals and their concentration in air:

\begin{tabular}{|l|c|c|c|c|}
\hline \multicolumn{2}{|c|}{} & Chromium in air & Nickel in air & Cobalt in air \\
\hline Serum chromium & $\mathrm{r}$ & 0.187 & & \\
& $\mathrm{p}$ & $0.056(>0.05)$ & & \\
\hline Serum nickel & $\mathrm{r}$ & & 0.171 & \\
& $\mathrm{p}$ & & $0.220(>0.05)$ & 0.290 \\
\hline Serum cobalt & $\mathrm{r}$ & & & $0.016(<0.05)^{*}$ \\
& $\mathrm{P}$ & & & \\
\end{tabular}

There is a fair +ve correlation between cobalt concentrations in air and in serum and this correlation is statistically significant, but there is no statistically significant correlation between serum and air levels of chromium and nickel.

*: statistically significant

Table (5): Correlation between duration of exposure and serum metal levels in exposed group:

\begin{tabular}{|c|c|c|c|c|c|}
\hline & $\begin{array}{c}-10 \text { years } \\
\text { No. }=14\end{array}$ & $\begin{array}{c}10-20 \\
\text { No. }=4\end{array}$ & $\begin{array}{c}>20 \\
\text { No.=12 }\end{array}$ & $\begin{array}{c}\text { r. } \\
\text { value }\end{array}$ & $\begin{array}{c}\text { P. } \\
\text { value }\end{array}$ \\
\hline Serum chromium & $4.91 \pm 4.85$ & $15.06 \pm 3.39$ & $5.69 \pm 4.27$ & 0.022 & 0.907 \\
\hline Serum nickel & $7.9 \pm 6.16$ & $12.6 \pm 7.74$ & $10.23 \pm 6.77$ & 0.136 & 0.475 \\
\hline Serum cobalt & $7.36 \pm 5.79$ & $6.29 \pm 5.81$ & $4.22 \pm 3.38$ & -0.259 & 0.167 \\
\hline
\end{tabular}

There is no statistically significant correlation between duration of exposure and serum metal levels.

Table (6): Prevalence of chromosomal breaks among the studied group:

\begin{tabular}{|c|c|c|c|c|c|}
\hline & GROUPS & No. & Mean & $\begin{array}{c}\text { Standard } \\
\text { deviation }\end{array}$ & P. value \\
\hline Chromosomal & Exposed & 30 & 26.0400 & 22.1583 & $0.001^{*}$ \\
breaks & Controls & 20 & 9.3500 & 10.6735 & \\
\hline
\end{tabular}

There is statistically significant increase in the level of chromosomal breaks among the exposed group.

*: statistically significant 
Table (7): Effects of different variables on the frequency of chromosomal breaks in exposed group:

\begin{tabular}{|c|c|c|c|c|}
\hline & & Mean & S.D. & P. value \\
\hline \multirow{2}{*}{ Sex } & Males (24) & 24.8583 & 21.3512 & 0.56 \\
& Females (6) & 30.7667 & 26.7807 & $(>0.05)$ \\
\hline \multirow{2}{*}{ Smoking } & Smokers (11) & 30.5455 & 25.7347 & 0.41 \\
& Non smokers (19) & 23.4316 & 20.0878 & $(>0.05)$ \\
\hline \multirow{2}{*}{ PPE } & Users (18) & 21.8111 & 22.2400 & 0.2 \\
& Non users (12) & 32.3833 & 21.3741 & $(>0.05)$ \\
\cline { 2 - 4 } & &
\end{tabular}

There was no statistically significant difference due to the effect of sex, smoking or use of personal protective equipments on chromosomal breaks.

Table (8): Effects of different variables on the frequency of chromosomal breaks in exposed group:

\begin{tabular}{|l|c|c|}
\hline \multicolumn{2}{|l|}{} & $\begin{array}{c}\text { Chromosomal } \\
\text { breaks }\end{array}$ \\
\hline Age & $\mathrm{r}$ & 0.128 \\
& $\mathrm{p}$ & $0.502(>0.05)$ \\
\hline Duration of exposure & $\mathrm{r}$ & 0.110 \\
& $\mathrm{p}$ & $0.563(>0.05)$ \\
\hline Smoking index & $\mathrm{r}$ & 0.266 \\
& $\mathrm{p}$ & $0.155(>0.05)$ \\
\hline Serum Chromium & $\mathrm{r}$ & 0.438 \\
& $\mathrm{p}$ & $0.015(<0.05)^{*}$ \\
\hline Serum Nickel & $\mathrm{r}$ & 0.342 \\
& $\mathrm{p}$ & $0.064(>0.05)$ \\
\hline Serum Cobalt & $\mathrm{r}$ & 0.131 \\
& $\mathrm{p}$ & $0.491(>0.05)$ \\
\hline
\end{tabular}

There is +ve correlation between smoking index , metal levels in serum with frequency of chromosomal breaks, but this correlation was statistically significant only in serum chromium level. No statistically significant effect of age or duration of exposure and frequency of chromosomal breaks.

*: statistically significant 
Table (9): Correlation between age, duration of exposure and frequency of chromosomal breaks:

\begin{tabular}{|c|c|c|c|c|}
\hline \multirow{2}{*}{} & \multicolumn{3}{c|}{ Chromosomal breaks \% } \\
\cline { 3 - 5 } \multicolumn{2}{|c|}{} & Mean & $\begin{array}{c}\text { P. } \\
\text { value }\end{array}$ & $\begin{array}{c}\text { r. } \\
\text { value }\end{array}$ \\
\hline Age & $<40$ years & $25.2 \%$ & 0.502 & 0.128 \\
\cline { 3 - 4 } & $>40$ years & $28 \%$ & & 0.11 \\
\hline Duration of exposure & $<15$ years & $24.9 \%$ & 0.563 & \\
\cline { 2 - 3 } & $>15$ years & $27.7 \%$ & & 0.11 \\
\hline
\end{tabular}

There is increase of chromosomal breaks \% with increasing age and duration of exposure but this increase is not statistically significant. 

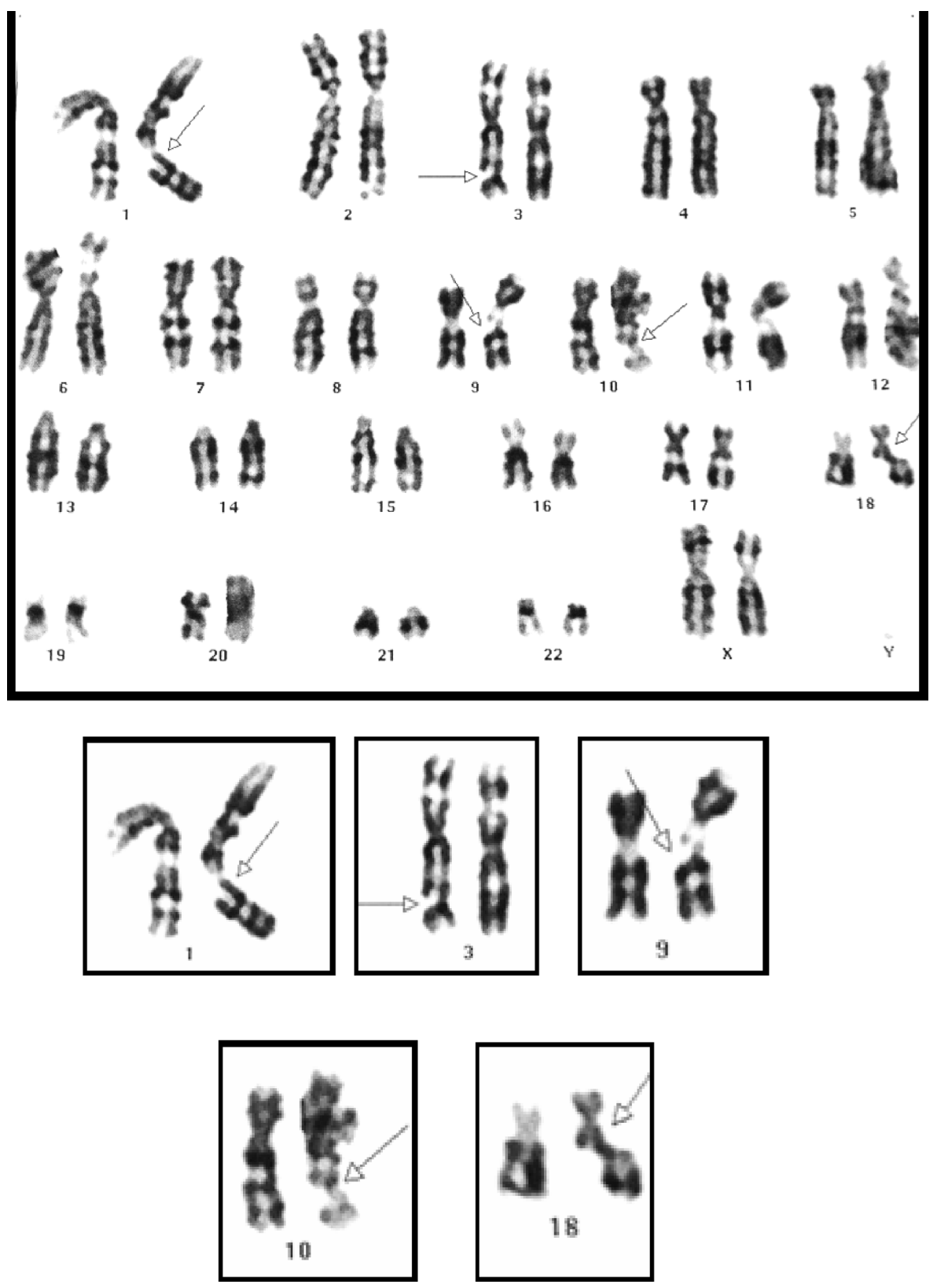

Fig.(1): A metaphase spread using bleomycin in an exposed subject: showing chromosomal breaks in chromosomes no. $1,3,9,10 \& 18$. 

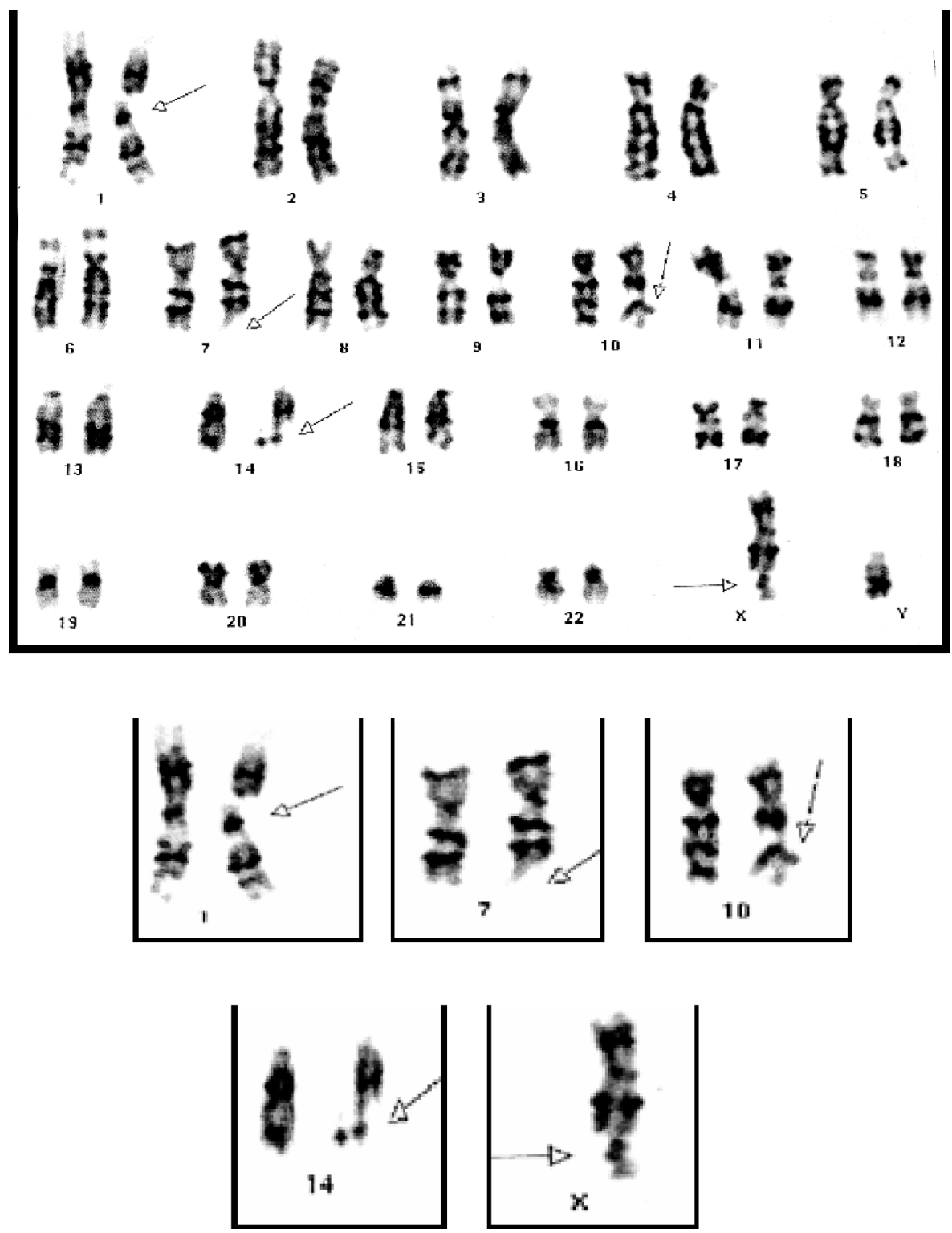

Fig.(2): A metaphase spread using bleomycin in an exposed subject: showing chromosomal breaks in chromosomes no. $1,7,10,14 \& \mathrm{X}$. 

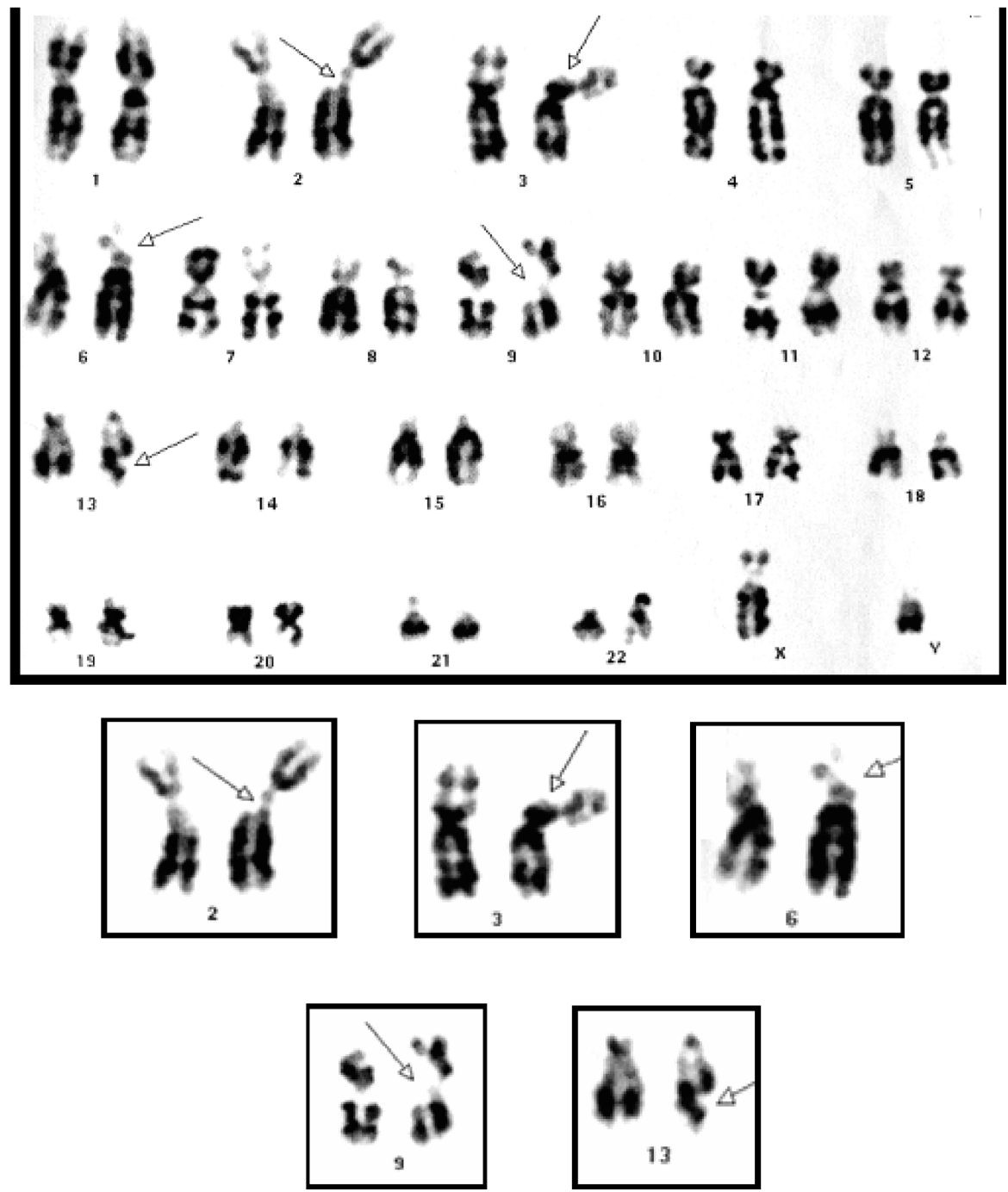

Fig.(3): A metaphase spread using bleomycin in an exposed subject: showing chromosomal breaks in chromosomes no. $2,3,6,9 \& 13$. 

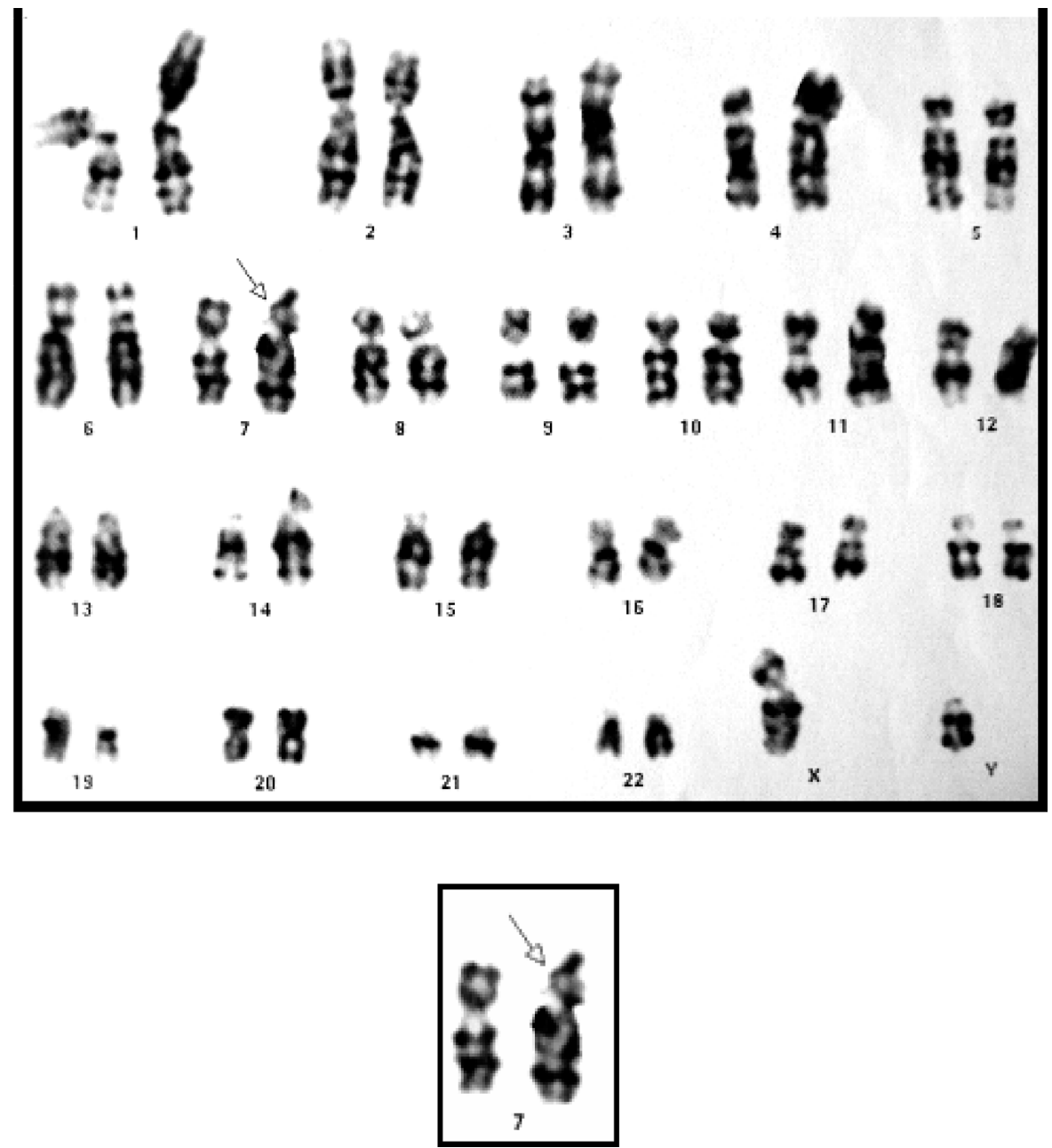

Fig.(4): A metaphase spread using bleomycin in a control subject: showing chromosomal breaks in chromosome no. 7 . 


\section{Discussion}

Dental technicians could be exposed to a number of toxic materials including metal alloys that have been identified as potential health hazards. Metallic alloys such as Vitallium, Duralium, Wironit, and Remanium are used in the production of crowns, bridges and dental prosthesis. The most common constituents of these prosthesis are chromium, nickel, cobalt, molybdenum, silica and other metals in different amounts (Sherson et al., 1990).

Leghissa et al., 1994 have pointed out that dental technicians have a risk of inhaling cobalt and chromium during casting and finishing processes in the production of skeletal prosthesis. Their data were based on both air born and urinary cobalt and chromium measurements.

Dental technicians in this study were involved in all steps of formation of prosthesis production including casting and finishing operations. No statistically significant difference between age, sex or smoking habits between cases and controls as shown in table (1).

Our study showed that there was highly statistically significant increase of serum level of chromium, nickel and cobalt among dental technicians as compared to controls, as shown in table (2). Serum Cr.,
Ni. and Co. levels in exposed were $6.576 \pm 5.5017, \quad 9.467 \pm 6.5885$ and $5.9647 \pm 5.0067 \mu \mathrm{g} / \mathrm{L}$ respectively. These levels were higher than the reference values proposed by the American Conference of Governmental Industrial Hygienists (ACGIH) 1998. Similar results were obtained by Burgaz et al, 2002, who detected a statistically significant increase in the urinary level of chromium, nickel and cobalt in dental laboratory technicians more than controls in their study on 27 male dental laboratory technicians in 7 dental laboratories in the city of Ankara, Gazi University and 15 healthy control subjects.

Exposed workers were asked about the use of personal protective equipments and it was evident that $60 \%$ of them were using masks and gloves as shown in table (3). The use of personal protective equipments led to the decrease in the serum levels of chromium, nickel and cobalt. This decrease was statistically significant in chromium and nickel levels. These results were matched with the results obtained by Jelmert et al., 1994 who detected a decrease in the serum level of chromium and nickel with the use of personal protective equipments in their study on 42 stainless steel welders.

Environmental studies of chromium, nickel and cobalt showed that the level of 
the 3 metals were within the $8 \mathrm{~h}$ TWA putted by OSHA, 2006, and that nickel had the highest level. It was evident from the study of materials used by the technicians that nickel constitutes the highest percentage of the most commonly used alloy which is: wiron nickel chrome alloy $(75 \%$ nickel and 25\% chromium). (BEGO, Bremen, Germany).

Our study showed that there is poor correlation between serum and air levels of chromium and nickel but a statistically significant positive correlation between serum and air level of cobalt: table (4). This was not matched with the results obtained by Jelmert et al., 1994, who found a positive correlation between chromium in air and in the serum of welders. When we asked the technicians we found that in their private work they use mostly the nickel chrome alloys not the cobalt chrome alloys, while in their official work they use the 3 metals, and as we were not able to measure the air levels of metals in the private labs in which they work except only one lab. due to the lack of cooperation; this could explain that the total exposure to $\mathrm{Cr}$. and $\mathrm{Ni}$. couldn't be fully assessed, while the total exposure to cobalt is fully assessed as it is only used in the official labs. in which we measured the air levels of the metals.
When we correlate the serum level of chromium, nickel and cobalt and duration of exposure (table 5), we found that there was no statistically significant difference between duration of exposure and the serum levels of the three metals although all of them decreased after 20 years. This was matched with the results obtained by Jelmert et al., 1994, who detected that the blood level of chromium and nickel decreased with the increase in the duration of exposure on his study done on 42 welders of stainless steel in Norway. This was explained by that young workers had lack of experience and were working in less ventilated areas and that those with more experience work in larger laboratories and with better ventilation.

Our study showed that there was no statistically significant correlation between smoking habit or smoking index and the serum metal levels. These results were concomitant with the results obtained by Burgaz et al., 2002, who found that there was no effect of smoking on serum level of chromium, nickel and cobalt in dental laboratory technicians.

Several results indicate that, metallic chromium, chromium (III) and chromium (VI) could induce a variety of genetic and related effects in vitro, as reviewed by De Flora et al., 1990. However, there are very 
few studies on the genotoxicity risk of dental technicians.

Exposure of dental technicians in this study to chromium, nickel and cobalt was assessed from serum and air levels. The concentrations of chromium, nickel and cobalt in the serum of technicians were significantly elevated, confirming occupational exposure to these metals and also serum levels were above the reference values which are $<0.5 \mu \mathrm{g} / \mathrm{L}$ for the three metals (Lauwerys and Hoet, 1993; ACGIH, 1998).

Previous studies of workers exposed to chromium, nickel and cobalt using some cytogenetic end-points, such as SCE, CA, DNA strand breakages and DNA-protein crosslinks have yielded conflicting results. Inconsistency of these results may be explained on the basis of different exposure levels of chromium, nickel and cobalt and also different sensitivities of cytogenetic end-points (Massé et al., 2003; Ladon et al., 2004; Roman et al., 2005).

In the present study, in the normal karyotyping there was no chromosomal aberration in peripheral blood lymphocytes of dental laboratory technicians, and after induction of breakage culture by using bleomycin as breakage inducer, they showed significantly higher levels of chromosomal breaks as compared to control subjects. (P. value $=0.001)$ as seen in table (6). Non of the controls exceeded the $35 \%$ level of chromosomal breaks as shown in figure (4) and 11 of the exposed had breaks $\geq 35 \%$ as shown in figures (1-3). Similar results were obtained by Burgaz et al., 2002, who found significant increase of micronucleated lymphocytes in laboratory dental technicians exposed to chromium, nickel and cobalt as compared to control subjects.

On studying the effect of sex on chromosol breaks, we found that there was no statistically significant difference on chromosomal breaks among the exposed group (table 7). These results were in accordance with the results obtained by Knudsen et al., 1999, who found no effect of sex on chromosomal aberrations on their study on bus drivers exposed to urban air pollution.

One of the most important findings in this study was that 4 out of the 6 females (about 66\%) included in the study suffered from repeated abortions, still births and small sized fetuses and that they couldn't get pregnant except after a long vacation for at least 1 year. This was matched with the results obtained by Elbetieha and AlHamood 1997, who reported that exposure of male mice to $5000 \mathrm{ppm} \mathrm{Cr}$ III compounds for 12 weeks had adverse impacts on male fertility. The number of implanta- 
tion sites and viable fetuses were significantly reduced in females. The results of this study suggest the potential presence of reproductive hazards due to exposure to these metals.

Nickel is associated with an increase in perinatal mortality and growth retardation in offspring of rats exposed to nickel in drinking water (Smith et al., 1993). An increase in spontaneous abortion (15.9\%) was observed among women who worked in a nickel refining plant in Russia compared to controls $(8.5 \%)$. Also there was significant increase in structural malformations among babies born to the workers (16.9\%) compared to those born to the controls (5.8\%) (Chashschin et al., 1994).

Our study showed that there was an increase in the frequency of chromosomal aberrations among smokers than non smokers but this increase was not statistically significant (table 7), and no statistically significant correlation between smoking index and chromosomal aberrations as shown in table (8). This was matching with the results obtained by Burgaz et al., 2002, who also found that there was no significant effect of smoking habit on the induction of $\mathrm{MN}$ in lymphocytes and nasal mucosa cells of dental laboratory technicians.
The use of personal protective equipments decreased the mean value of chromosomal breaks when we compared the users with the non users but not to a statistically significant level as shown in table (7). Also as we mentioned before that the use of personal protective equipments decreased much the serum levels of metals (table 3). These results were matched with the results obtained by Jelmert et al., 1994, who found on his study among 42 stainless steel welders that the use of personal protective equipments significantly decreased the chromosomal aberrations.

There was no statistically significant effect of age on the chromosomal breaks as shown in tables $(8,9)$. This was concomitant with the results obtained by Burgaz et al., 2002, who found no effect of age on the MN frequency in lymphocytes and nasal mucosa cells of laboratory dental technicians.

This study showed an increase in the frequency of chromosomal aberrations with the increase in the duration of exposure but this increase was not statistically significant as shown in tables $(8,9)$. This was also matching with the results obtained by Elias et al., 1989, who found no statistically significant correlation between duration of exposure and chromosomal aberrations among welders. 
Roman et al., 2005 found that exposed workers in a metal plating factory for more than 15 years showed lower level of chromosomal aberrations than those with less than 15 years exposure, but this decrease was not statistically significant. This could be explained by the presence of some adaptive mechanisms. Also as we mentioned before the duration of exposure did not affect the serum metal levels significantly in our study.

Our study showed no statistically significant correlation between chromosomal breaks and the serum level of nickel and cobalt as shown in table (8). This was similar with the results obtained by Burgaz et al., 2002, who found that no relationship between the urinary nickel and cobalt level and $\mathrm{MN}$ frequencies in the peripheral lymphocytes of dental laboratory technicians.

The study of serum chromium level and chromosomal breaks showed a statistically significant correlation: table (8). This was consistent with many studies indicating genotoxic effects of chromium for example Wu et al, 2001 who detected statistically significant correlation between increased level of SCE in peripheral blood lymphocytes and increased $\mathrm{Cr}$. level among 35 electroplating workers in Taiwan.
This study suggest that exposed technicians had a great liability for chromosomal aberrations although the environmental study detect that the level of Cr., Ni., \& Co. are within the norms of the TLVs. This may raise the question of reconsidering these TLVs. However, as these workers are simultaneously exposed to these metals, there may be synergistic and antagonistic interactions between them (Katsifis et al., 1996; Cross et al., 2001); thus it is difficult to determine which compound(s) are responsible for the genotoxic damage observed in this study.

Based on the literature data on exposure analysis of dental technicians (Nayebzadeh et al., 1999) and on the approximate composition of base metal alloys used in dental laboratories as well as their known carcinogenic and/or genotoxic activities, the primary focus has been on chromium, nickel and cobalt as the major risk factors for occupational exposure to metallic alloys for this group of workers. However, this may not exclude that some other metals in small amounts in alloys such as Mo (Holland et al., 1998) and also inorganic particles such as silica (Ding et al., 2000) might modify the genotoxic effects observed in our study. 


\section{Conclusion And Recommendations}

From the present study, we conclude that dental laboratory technicians had statistically significantly higher percentage of chromosomal breaks with bleomycin induction than controls.

The serum levels of $\mathrm{Cr}$, $\mathrm{Ni}$ and $\mathrm{Co}$ were statistically significantly higher among dental laboratory technicians when compared to the controls.

There was a statistically significant positive correlation between serum chromium level and frequency of chromosomal breaks.

The use of personal protective equipments decreased the serum levels of chromium, nickel \& cobalt and this decrease was statistically significant in chromium and nickel.

The study showed that 4 of the 6 exposed females (about 66\%) included in the study suffered from repeated abortions, still births and small sized fetuses and that they couldn't get pregnant except after a long vacation for at least 1 year. This indicates that $\mathrm{Cr}, \mathrm{Ni}$ and $\mathrm{Co}$ could have a genotoxic effect.

From the present study we recommend the following:

1- Environmental monitoring is highly recommended in dental laboratories to en- sure that permissible levels of different hazardous agents are not exceeded.

2- Health education of workers about the hazards of contact or inhalation of the harmful agents and proper measures for protection is essential.

3- The use of personal protective equipments e.g. gloves, masks and coats should be encouraged by dental laboratory technicians.

4- Applying hygienic measures: All workers should be encouraged to wash their hands several times during the day especially before drinking and eating and to take shower at the end of the day and to change their clothes.

5- Serum metal levels can be used as indicator of metal exposures among dental laboratory technicians.

6- Any history about gestational problems should be well investigated.

7- Periodic medical examination including measurement of serum metal level to detect any early increase of the metal levels, and chromosomal studies using bleomycin as a stimulator for early detection of any susceptibility for chromosomal damage are essential.

8- Reconsidering the TLVs for the air metal levels. 


\section{References}

1. BEGO company, Bremen, Germany. www.bego.com

2. Benova D., Hadjidekova V., Hristova R., Nikolova T., Boulanova M., Georgieva I., Grigorova M., Popov T., Panev T., Georgieva R., Natarajan A.T., Darroudi F. and Nilsson R. (2002) Cytogenetic effects of hexavalent chromium in Bulgarian chromium platters. Mutation Research; 514: 29-38.

3. Burgaz s., Demircigil G.C., Yilmazer M., Ertas N., Kemaloglu Y. and Burgaz Y. (2002) Assessment of cytogenetic damage in lymphocytes and in exfoliated nasal cells of dental laboratory technicians exposed to chromium, cobalt and nickel. Mutation research; 521: 47-56.

4. Chashschin V.P., Artunina G.P. and Norseth T. (1994) Congenital defects, abortion and other health effects in nickel refinery workers. Sci. Total Environ.; 148: 287-291.

5. Christensen J.M., Kristiansen J., Nielsen N.H., Menné T. and Byrialsen K. (1999) Nickel concentrations in serum and urine of patients with nickel eczema. Tocicology Letters; 108: 185189.

6. Cross D.P., Ramachandran G. and Wattenberg E.V. (2001) Mixtures of nickel and cobalt chlorides induce synergistic cytotoxic effects: implications for inhalation exposure modeling. Ann. Occup. Hyg.; 45: 409-418.

7. De Flora S., Banasco M., Serra D. and Zanacchi P. (1990) Genotoxicity of chromium compounds: A review. Mutat. Res.; 112: 238-299.

8. Ding M., Shi X., Castranova V. and Vallyathan V. (2000) Predisposing factors in occupational lung cancer: inorganic minerals and chromium.
J. Environ. Pathol. Toxicol. Oncol.; 19 (1): 129138.

9. Elbetieha A. and Al-Hamood M.H. (1977) Longterm exposure of male and female mice to trivalent and hexavalent chromium compounds: effects on fertility. Toxicology; 116: 39-47.

10. Elias Z., Mur J.M., Pierre F., Gilgenkrantz S., Schneider O., Baruthio F., Danière M.C. and Fontana J.M. (1989) Chromosomal aberrations in peripheral blood lymphocytes of welders and characterization of their exposure by biological sample analysis. Journal of Occupational Medicine; 31(5): 477-483.

11. Holland N.T., Shao J., Zhang L., Xi L., Ngo H., Shang N. and Smith M.T. (1998) Studies on the genotoxicity of Molybdenum salts in human cells in vitro and mice in vivo. Environ. Mol. Mutagen.; 32 (3): 25-259.

12. Jelmert Ø., Hansteen I.L. and Langård S. (1994) Chromosome damage in lymphocytes of stainless steel welders related to past and current exposure to manual metal arc welding fumes. $\mathrm{Mu}-$ tation Research/Genetic Toxicology; 320(3): 223-233.

13. Katsifis S.P., Kinney P.L., Hosselet S., Burns F.J. and Christie N.T. (1996) Interactions of nickel with mutagens in the induction of sister chromatid exchanges in human lymphocytes. Mutation research/Environmental mutagenesis and related subjects; 359 (1): 7-15.

14. Knudsen L.E., Norppa H., Gamborg M.O., Nielsen P.S., Okkels H., Järrentaus H and Autrup H. (1999) Chromosomal aberrations in humans induced by urban air pollution: Influence of DNA repair and polymorphism of glutathione $\mathrm{S}$ transferase M1 and N-acetyltransferase 2. Cancer Epidemiology, Biomarkers and Prevention; 8: 303-310. 
15. Ladon D., Doherty A., Newson R., Turner J., Bhamra M. and Case C.P. (2004) Changes in metal levels and chromosome aberrations in the peripheral blood of patients after metal-on-metal hip arthroplasty. The Journal of Arthroplasty; 19(8): 78-83.

16. Lauwerys R. and Hoet P. (1993) Industrial chemical exposure: Guidelines for biological monitoring Boca Raton: Lewis.

17. Leghissa P., Ferrari M.T., Piazzolla S., Caironi M., Parigi P.C. and Lebbolo E. (1994) Cobalt exposure evaluation in dental prosthesis production. Sci. Total Environ.; 150: 253-257.

18. Lide D.R. (1998) Handbook of chemistry and physics. 78th. Edition. CRC press, American chemical society.

19. Massè A., Bosetti M., Buratti C., Visentin O., Bergadano D. and Camnnas M. (2003) Ion release and chromosomal damage from total hip prostheses with metal-on-metal articulation. Journal of Biomedical Materials Research Part B: Applied Biomaterials; 67 B(2): 750-757.

20. Moorhead P.S., Nowell P.C., Mellman W.L., Battips D.M. and Hungerford D.A. (1960) Chromosome preparations of leukocytes cultured from human peripheral blood. Exp. Cell. Res.; 20: 613-616.

21. Nayebzadeh A., Dufresne A., Harvie S. and Begin R. (1999) Mineralogy of lung tissue in dental laboratory technicians' pneumoconiosis. Am. Ind. Hyg. Assoc. J.; 60: 349-353

22. OSHA (Occupational Safety and Health Administration). (2006) Health effects discussion and determination of final PEL. www.osha.gov/pls/ oshaweb
23. Park R.M., Bena J.F., Stayner L.T., Smith R.J., Gibb H.J. and Lees P.S.J. (2004) Hexavalent chromium and lung cancer in chromate industry: A quantitative risk assessment. Risk analysis; 24 (5): 1099-1108.

24. Roman I., Simirad S. and Florea A.M. (2005) Cytogenetic changes in workers occupationally exposed to complex mixtures in a metal-plating factory. Institute of Public Health Lasi.

25. Rooney D.E. and Czepulkowski B.H. (1992) Human cytogenetics. A practical approach. Vol. II. Chapter 8. Page 115. Oxford university press. New York.

26. Sherson D., Maltbaek N. and Heydorn K. (1990) A dental technician with pulmonary fibrosis: a case of chromium-cobalt alloy pneumoconiosis. Eur. Respir. J.; 3: 1227-1229.

27. Smith M.K., George E.L., Stober J.A., Feng H.A. and Kimmel G.L. (1993) Perinatal toxicity associated with nickel chloride. Environmental Research; 61: 200-211.

28. Winder C. and Stacey N. (2004) Occupational toxicology, 2nd Edition, chapter 12; toxicity of metals: 316-318. CRC press.

29. Wise S.S., Holmes A.L., Ketterer M.E., Hartsock W.J., Fomchenko E., Katsifis S., Thompson W.D. and Wise J.P. (2004) Chromium is the proximate clastogenic species for lead-chromate induced clastogenicity in human bronchial cells. Mutation Research; 560: 79-89.

30. Wu F.Y., Wu W.Y., Kuo H.W., Liu C.S., Wang R.Y. and Lai J.S. (2001) Effects of genotoxic exposure to chromium among electroplating workers in Taiwan. The Science of the Total Environment; 279: 21-28. 